\title{
PENGARUH RETURN ON ASSETS (ROA), NON PERFORMING LOAN (NPL), DAN CAPITAL ADEQUACY RATIO (CAR) TERHADAP PERTUMBUHAN LABA \\ (Studi pada PT BPR Cianjur periode 2007-2016)
}

\author{
Muhammad Ali \\ Email : muhammad.ali@widyatama.co.id \\ Fakultas Ekonomi - Universitas Widyatama Bandung - \\ Indonesia
}

\begin{abstract}
The purpose of this study is determining how much influence of Return On Assets (ROA), Non Performing Loan (NPL) and Capital Adequacy Ratio (CAR) either partially or simultaneously toward of Earnings Growth at PT BPR Cianjur in periode 2007-2016. The methods used in this research are descriptive and associative methods. To determine the influence of these variables used multiple linear regression analysis. And than doing hypotesis test of partial t test and $F$ test of simultaneously using application software SPSS 22. The Result of this study shows an average of the year 2007-2016 from Return on Assets (ROA) amounted to 4,4230, Non Performing Loan (NPL) amounted to 7,6630, Capital Adequacy Ratio (CAR) amounted 35,2110, and Earnings Growth amounted 22,20. Based upon the research, there is results that Return On Assets (ROA), Non Performing Loan (NPL) is not significant on Earnings Growth, and Capital Adequacy Ratio (CAR) have positive significant effect on Earnings Growth. The simultaneous Return On Assets (ROA), Non Performing Loan (NPL) and Capital Adequacy Ratio (CAR) significantly effects on Earnings Growth.
\end{abstract}

Keywords : Return On Assets (ROA), Non Performing Loan (NPL) and Capital Adequacy Ratio), and Earnings Growth.

\section{PENDAHULUAN}

Bank merupakan suatu lembaga yang berperan sebagai perantara keuangan (finansial intermediary) antara pihak-pihak yang memiliki dana (surplus unit) dengan pihak-pihak yang memerlukan dana, serta sebagai lembaga yang berfungsi memperlancar aliran lalu lintas pembayaran. Di samping itu, bank juga sebagai suatu industri yang dalam kegiatannya mengendalikan kepercayaan masyarakat sehingga tingkat kesehatan bank perlu dipelihara.

Laba atau profit merupakan salah satu indikator kinerja suatu perusahaan dan dijadikan tolak ukur dalam mengukur kinerja perusahaan. Secara umum, laba dijadikan dasar dalam pengambilan keputusan para investor dan kreditor dalam penanaman modalnya. Pada mulanya pertumbuhan laba merupakan

(20) Urama $\quad$ Muhamad Ali 1185


kenaikan atau penurunan laba per tahun. Dengan adanya perubahan laba yang tinggi mengindikasikan laba yang diperoleh perusahaan juga tinggi.

Selain itu, laba juga merupakan salah satu indikator penting dalam menilai kesehatan bank, yaitu penilaian dari segi profitabilitasnya. Pengukuran profitabilitas salah satunya menggunakan rasio Return On Asset (ROA) yang merupakan rasio jumlah laba bersih sebelum pajak dengan total aktiva. Semakin besar ROA yang dimiliki bank, maka semakin besar pula tingkat keuntungan yang diperoleh bank dan semakin baik pula posisi tersebut dari segi penggunaan aset. Dengan kata lain, Return On Assets (ROA) dapat menunjukkan efisiensi manajemen dalam penggunaan aset untuk mendapatkan keuntungan

Dan yang kedua yang mempengaruhi pertumbuhan laba terhadap perusahaan yaitu Non Performing Loan (NPL). NPL merupakan rasio yang dipergunakan untuk mengukur kemampuan bank dalam meng-cover risiko kegagalan pengembalian kredit oleh debitur. Besarnya NPL menjadi salah satu penyebab sulitnya perbankan dalam menyalurkan kredit.

Tingkat kecukupan modal pada perbankan diwakilkan dengan rasio Capital Adequacy Ratio (CAR). Rasio CAR merupakan kemampuan bank dalam menyediakan modal untuk kepentingan operasi perusahaan perbankan dan sebagai penampung risiko kerugian dana akibat aktivitas operasi bank (Tommy, 2014).

Rasio kecukupan modal merupakan perbandingan modal bank dengan aktiva tertimbang menurut risiko. Semakin tinggi rasio CAR mengindikasikan bank tersebut semakin sehat permodalannya. Rasio ini dimaksudkan untuk menilai keamanan dan kesehatan perusahaan dari sisi modal pemiliknya. Pemenuhan CAR minimum $8 \%$ mengindikasikan bahwa bank mematuhi regulasi permodalan (Frianto, 2012).

Hasil penelitian terdahulu dari Muhammad Isnaini Fathoni, dkk (2012: 1525) mengemukakan bahwa dari variabel-variabel yang diteliti, diperoleh hasil yang mempengaruhi pertumbuhan laba bank yang terdaftar di BEI periode 20072010 adalah CAR, NPL, dan ROA. Di mana variabel CAR dan ROA berpengaruh positif terhadap Pertumbuhan Laba, sedangkan variabel NPL berpengaruh negatif terhadap Pertumbuhan Laba.

Berdasarkan hasil analisis peneliti mengenai ROA terhadap pertumbuhan laba di PT BPR Cianjur ditemukan fenomena sebagaimana disajikan pada tabel 1.1 di bawah ini.

Tabel 1.1

Tingkat ROA dan Pertumbuhan Laba PT BPR Cianjur Jabar Periode tahun 2007-2016 (dalam persentase)

\begin{tabular}{|c|l|l|c|l|c|}
\hline Tahun & ROA & Perubahan & Pertumbuhan laba & Perubahan & Fenomena \\
\hline 2007 & 6,76 & - & 13 & - & \\
\hline 2008 & 5,60 & Turun & 19 & Naik & Ada \\
\hline 2009 & 7,24 & Naik & 86 & Naik & Tidak Ada \\
\hline 2010 & 7,67 & Naik & 5 & Turun & Ada \\
\hline 2011 & 3,19 & Turun & 23 & Naik & Ada \\
\hline 2012 & 3,06 & Turun & 38 & Naik & Ada \\
\hline
\end{tabular}




\begin{tabular}{|c|c|l|c|l|c|}
\hline 2013 & 3,10 & Naik & 6 & Turun & Ada \\
\hline 2014 & 2,59 & Turun & 4 & Turun & Tidak Ada \\
\hline 2015 & 2,70 & Naik & 15 & Naik & Tidak Ada \\
\hline 2016 & 2,32 & Turun & 13 & Turun & Tidak Ada \\
\hline
\end{tabular}

Sumber : Data Perusahaan tahun 2007-2016 yang telah diolah kembali

Berdasarkan di atas diketahui nilai dapat dilihat bahwa dari tahun 2007 2016 pengaruh Return On Assets (ROA) mengalami peningkatan dan penurunan (fluktuasi). Pada tahun 2008 nilai ROA terjadi penurunan hal ini mengakibatkan pertumbuhan laba menjadi menurun, tetapi dalam kenyataannya data perusahaan bertolak belakang. Sama halnya pada tahun 2010-2013 hal tersebut menjadikan sebuah fenomena dan tidak sesuai dengan teori yang telah ditetapkan.

Berdasarkan hasil analisis peneliti, ditemukan fenomena NPL dan pertumbuhan laba di PT BPR Cianjur sebagaimana disajikan pada tabel 1.2 di bawah ini.

Tabel 1.2

Tingkat NPL dan Pertumbuhan Laba PT BPR Cianjur Jabar Periode tahun 2007-2016 (dalam persentase)

\begin{tabular}{|c|c|l|c|l|c|}
\hline Tahun & NPL & Perubahan & $\begin{array}{c}\text { Pertumbuhan } \\
\text { laba }\end{array}$ & Perubahan & Fenomena \\
\hline 2007 & 5,64 & - & 13 & & - \\
\hline 2008 & 5,41 & Turun & 19 & Naik & Tidak Ada \\
\hline 2009 & 4,10 & Turun & 86 & Naik & Tidak Ada \\
\hline 2010 & 3,72 & Turun & 5 & Turun & Ada \\
\hline 2011 & 11,73 & Naik & 23 & Naik & Ada \\
\hline 2012 & 11,86 & Naik & 38 & Naik & Ada \\
\hline 2013 & 9,69 & Turun & 6 & Turun & Ada \\
\hline 2014 & 7,39 & Turun & 4 & Turun & Ada \\
\hline 2015 & 7,60 & Naik & 15 & Naik & Ada \\
\hline 2016 & 9,49 & Naik & 13 & Turun & Tidak Ada \\
\hline
\end{tabular}

Sumber : Data Perusahaan tahun 2007-2016 yang telah diolah kembali

Berdasarkan tabel $1.2 \mathrm{di}$ atas diketahui tingkat kredit bermasalah cenderung lebih tinggi di tahun ke 5 dan tidak sebanding dengan tingkat jumlah asset yang ada di bank. Tingkat fluktuasi dari tahun ke tahunnya tidak stabil. Dan terjadi fenomena pada tahun 2010-2015 di mana ketika nilai NPL turun dan nilai pertumbuhan laba turun. Dan tahun ketika nilai NPL naik dan nilai pertumbuhan laba justru hasilnya naik juga. Hal tersebut menjadikan sebuah fenomena dan tidak sesuai dengan teori yang telah ditetapkan.

Berdasarkan hasil analisis peneliti, terjadi fenomena mengenai CAR dan pertumbuhan laba di PT BPR Cianjur yang disajikan pada tabel 1.3 di bawah ini. 
Tabel 1.3

Tingkat CAR dan Pertumbuhan Laba PT BPR Cianjur Jabar

Periode tahun 2007-2016

(dalam persentase)

\begin{tabular}{|c|c|l|c|l|c|}
\hline Tahun & CAR & Perubahan & $\begin{array}{c}\text { Pertumbuhan } \\
\text { Laba }\end{array}$ & Perubahan & Fenomena \\
\hline 2007 & 36,87 & - & 13 & - & \\
\hline 2008 & 38,39 & Naik & 19 & Naik & Tidak Ada \\
\hline 2009 & 42,91 & Naik & 86 & Naik & Tidak Ada \\
\hline 2010 & 41,01 & Turun & 5 & Turun & Tidak Ada \\
\hline 2011 & 31,56 & Turun & 23 & Naik & Ada \\
\hline 2012 & 33,72 & Naik & 38 & Naik & Tidak Ada \\
\hline 2013 & 33,77 & Naik & 6 & Turun & Ada \\
\hline 2014 & 36,73 & Naik & 4 & Turun & Ada \\
\hline 2015 & 30,72 & Turun & 15 & Naik & Ada \\
\hline 2016 & 26,43 & Turun & 13 & Turun & Tidak Ada \\
\hline
\end{tabular}

Sumber : Data Perusahaan tahun 2007-2016 yang telah diolah kembali

Berdasarkan tabel 1.3 di atas diketahui tingkat CAR dari tahun 20072009 mengalami peningkatan menjadi 42,91\%, kemudian mengalami penurunan 2 tahun selanjutnya menjadi $31,56 \%$, sedangkan data pertumbuhan mengalami kenaikkan di tahun 2011 menjadi 23\%. Hal tersebut menjadikan sebuah fenomena dan tidak sesuai dengan teori yang telah ditetapkan.

Berdasarkan masalah yang telah dikemukakan di atas, maka penulis tertarik untuk menggali lebih dalam permasalahan tersebut dalam bentuk penelitian dengan judul, "PENGARUH RETURN ON ASSET (ROA), NON PERFORMING LOAN (NPL), DAN CAPITAL ADEQUACY RATIO (CAR) TERHADAP PERTUMBUHAN LABA (Studi pada PT BPR Cianjur periode 20072016).

\section{KAJIAN PUSTAKA}

\subsection{Return On Assets (ROA)}

Pengertian ROA menurut SEBI No. 6/23/DPNP 2014 dalam Frianto Pandia (2012:71) adalah sebagai berikut:

"Return on Assets (ROA) adalah rasio yang menunjukkan perbandingan antara laba (sebelum pajak) dengan total aset bank, rasio ini menunjukkan tingkat efisiensi pengelolaan aset yang dilakukan oleh bank yang bersangkutan".

Pengertian ROA menurut Tommy Setyono (2014) adalah sebagai berikut:

"Return On Assets (ROA) sebagai indikator performance suatu bank merupakan rasio yang digunakan untuk mengukur keefektivan bank dalam menghasilkan keuntungan dengan memanfaatkan seluruh aktiva yang dimiliki oleh bank. Semakin tinggi ROA semakin tinggi pula keefektifan bank dalam menghasilkan laba" 


\subsection{Non Performing Loan (NPL / Kredit Bermasalah)}

Assets quality adalah semua aktiva yang dimiliki oleh bank dengan maksud untuk dapat memperoleh penghasilan sesuai dengan fungsinya. (Muhammad Isnaini Fathoni,dkk: 2012:17).

Komponen faktor kualitas aset yang digunakan dalam penelitian ini adalah NPL (Non Performing Loan). Dipilihnya NPL dalam penelitian ini karena rasio NPL merupakan rasio yang berhubungan langsung dengan penanganan masalah kredit yang bermasalah, sehingga rasio ini dipandang lebih penting dalam menilai kualitas asset.

Membahas masalah kredit tidak lepas dari pembicaraan mengenai kredit bermasalah (non performing loan). Kredit bermasalah selalu ada dalam kegiatan perkreditan bank, karena bank tidak mungkin menghindarkan adanya kredit bermasalah.

Pengertian kredit macet menurut Gatot Supramono (2009: 268) adalah sebagai berikut:

"Kredit macet adalah kredit atau utang yang tidak dapat dilunasi oleh debitur karena sesuatu alasan sehingga bank selaku kreditur harus menyelesaikan masalahnya kepada pihak ketiga atau melakukan eksekusi barang jaminan".

Pengertian kredit macet menurut Siswanto Sutojo (2007:11) adalah sebagai berikut:

"Kredit bermasalah adalah debitur mengingkari janji mereka untuk membayar bunga dan atau kredit induk yang telah jatuh tempo. Sehingga, terjadi keterlambatan pembayaran atau sama sekali tidak ada pembayaran".

\subsection{Capital Adequacy Ratio (CAR)}

Menurut pasal 29 ayat 2 Undang-Undang Republik Indonesia No.10 tahun 1998 dalam Frianto (2012) CAR (Capital Adequacy Ratio) menyatakan:

"Dalam menjalankan fungsinya bank harus menjaga rasio kecukupan modalnya menilai kesehatan bank karena ini berhubungan dengan solvabilitas bank. Modal juga merupakan aspek yang sangat penting untuk CAR yang harus dicapai oleh bank umum itu ditetapkan sekitar $8 \%$ dari aktiva tertimbang menurut resiko (ATMR)".

\subsection{Pengaruh Return On Assets (ROA), Non Performing Loan (NPL) Capital Adequacy Ratio (CAR) terhadap Pertumbuhan Laba}

Pengaruh ROA, NPL, CAR terhadap pertumbuhan laba menurut Muhammad Isnaini Fathoni, dkk (2012) menunjukkan bahwa hasil pengujian secara parsial menunjukkan bahwa dari ketiga variabel independen yaitu Return On Asset, Non Performing Loan, Capital Adequacy Ratio berpengaruh positif dan signifikan terhadap pertumbuhan laba, pengujian secara simultan menunjukkan bahwa Return On Assets $\left(\mathrm{X}_{1}\right)$, Non Performing Loan $\left(X_{2)}\right.$, dan Capital Adequacy Ratio $\left(\mathrm{X}_{3}\right)$ semua berpengaruh positif dan signifikan terhadap pertumbuhan laba (Y). 
Berdasarkan tinjauan literatur dan penelitian terdahulu, dapat disusun paradigma penelitian yang tersaji sebagai berikut:

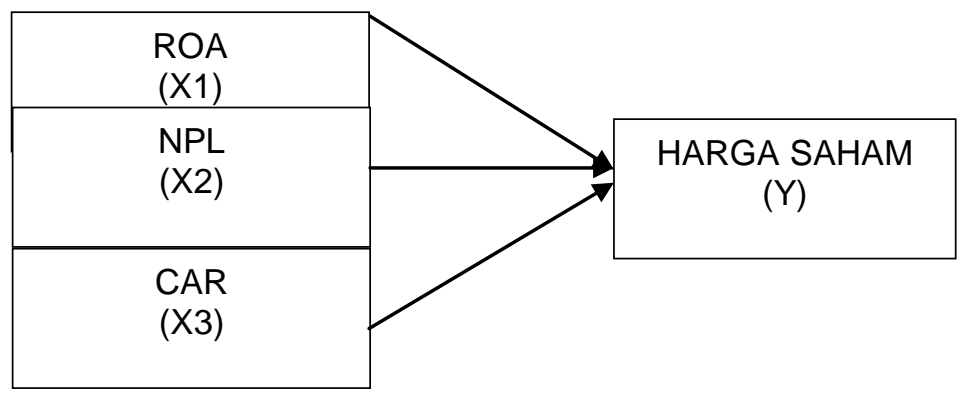

Gambar 2.1

Paradigma Penelitian

Berdasarkan telaah pustaka di atas maka hipotesis yang dapat dibuat dalam penelitian ini adalah:

$\mathrm{H}_{1}$ : Terdapat pengaruh ROA terhadap Pertumbuhan Laba pada PT BPR Cianjur periode 2017-2016.

$\mathrm{H}_{2}$ : Terdapat pengaruh NPL terhadap Pertumbuhan Laba pada PT BPR Cianjur periode 2017-2016.

H3 : Terdapat pengaruh CAR terhadap Pertumbuhan Laba pada PT BPR Cianjur periode 2017-2016.

$\mathrm{H}_{4}$ : Terdapat pengaruh ROA, NPL, dan CAR terhadap Pertumbuhan Laba pada PT BPR Cianjur periode 2017-2016.

\section{METODE PENELITIAN}

\section{3..1. Desain Penelitian}

Dalam penelitian ini, penulis menggunakan metode deskriptif dan metode asosiatif. Metode deskriptif ini digunakan untuk menganalisa data dengan cara mendeskripsikan atau menggambarkan data yang telah terkumpul.

Sedangkan metode asosiatif bersifat objektif yang mencakup pengumpulan dan analisis data kuantitatif untuk mengetahui hubungan dua variabel atau lebih, di dalam penelitian ini dibantu dengan menggunakan metode pengujian statistik.

Dan penelitian ini penulis menentukan Return On Asset (ROA) sebagai $X_{1}$, Non Performing Loan (NPL) sebagai $X_{2}$, Capital Adequacy Ratio (CAR) sebagai $\mathrm{X}_{3}$ dan pertumbuhan laba sebagai $\mathrm{Y}$.

\subsection{Data Dan Sumber Data}

Data yang digunakan dalam penelitian ini adalah data sekunder. Data dalam penelitian ini adalah laporan keuangan tahunan yang dikeluarkan oleh PT BPR Cianjur Jabar tahun 2007-2016. 


\subsection{Analisis Deskriptif}

Analisis deskriptif dilakukan untuk mengetahui dan menjelaskan karakteristik variabel-variabel dari sebuah situasi atau keadaan.

\subsection{Analisis Asosiatif}

Metode analisis asosiatif yang digunakan adalah analisis regresi linier berganda untuk melihat hubungan secara linear antara dua atau lebih variabel independen $\left(\mathrm{X}_{1}, \mathrm{X}_{2}, \ldots . \mathrm{X}_{\mathrm{n}}\right)$ dengan variabel dependen $(\mathrm{Y})$. Analisis ini untuk mengetahui arah hubungan antara variabel independen dengan variabel dependen apakah masing-masing variabel independen berhubungan positif atau negatif dan untuk memprediksi nilai dari variabel dependen apabila nilai variabel independen mengalami kenaikan atau penurunan. Data yang digunakan biasanya berskala interval atau rasio.

Persamaan regresi linear berganda sebagai berikut:

$$
\begin{aligned}
& Y=a+b_{1} X_{1}+b_{2} X_{2}+\ldots .+b_{n} X_{n} \\
& \text { Keterangan: } \\
& \mathrm{Y}=\text { Variabel dependen (nilai yang diprediksikan) } \\
& \mathrm{X}_{1} \text { dan } \mathrm{X}_{2}=\text { Variabel independen } \\
& \text { a } \quad=\text { Konstanta (nilai } Y \text { apabila } X_{1}, X_{2} \ldots . . X_{n}=0 \text { ) } \\
& \mathrm{b}=\text { Koefisien regresi (nilai peningkatan ataupun }
\end{aligned}
$$

penurunan)

(Sumber: Sugiyono, 2011: 262)

Sebelum dilakukan analisis linier berganda, terlebih dahulu dilakukan uji asumsi klasik.

Untuk dapat mengetahui apakah terdapat pengaruh variabel $X$ secara parsial terhadap variabel $Y$, maka dilakukan uji t. Sedangkan untuk pengaruh $\mathrm{X}_{1}$, $\mathrm{X}_{2}$ dan $\mathrm{X}_{3}$ secara bersamaan terhadap $\mathrm{Y}$ digunakan uji $\mathrm{F}$.

\subsection{Hipotesis Statistik Hipotesis 1}

$\mathrm{H}_{0}: \beta_{1}=0, \quad$ Tidak terdapat pengaruh ROA terhadap Pertumbuhan Laba

$\mathrm{H}_{1}: \beta_{1} \neq 0$, Terdapat pengaruh ROA terhadap Pertumbuhan Laba

Hipotesis 2

$\mathrm{H}_{0}: \beta_{2}=0, \quad$ Tidak terdapat pengaruh NPL terhadap Pertumbuhan Laba

$\mathrm{H}_{1}: \beta_{2} \neq 0$, Terdapat pengaruh NPL terhadap Pertumbuhan Laba

Hipotesis 3

$\mathrm{H}_{0}: \beta_{3}=0, \quad$ Tidak terdapat pengaruh CAR terhadap Pertumbuhan Laba

$\mathrm{H}_{1}: \beta_{3} \neq 0, \quad$ Terdapat pengaruh CAR terhadap Pertumbuhan Laba

Hipotesis 4

$\mathrm{H}_{0}: \beta_{1}=\beta_{2}=\beta_{3}=0$, Tidak terdapat pengaruh ROA, NPL dan CAR terhadap Pertumbuhan Laba

$\mathrm{H}_{1}: \beta_{1} \neq \beta_{2} \neq \beta_{3} \neq 0$, Terdapat pengaruh ROA, NPL dan CAR terhadap Pertumbuhan Laba 
ISSN

2460-030X

\section{HASIL DAN PEMBAHASAN}

\subsection{Analisis Deskriptif ROA pada PT BPR Cianjur periode 2007-2016} bawah ini

Hasil Return on Assets (ROA) sebagaimana disajikan pada Tabel $4.1 \mathrm{di}$

TABEL 4.1

Perkembangan Return On Asset (ROA)

PT BPR Cianjur, Jabar tahun 2007-2016

\begin{tabular}{|l|l|r|l|l|}
\hline No. & Tahun & ROA $(\%)$ & \multicolumn{2}{|l|}{ Perkembangan } \\
\hline 1. & 2007 & 6,76 & - & - \\
\hline 2. & 2008 & 5,60 & $-1,16 \%$ & Turun \\
\hline 3. & 2009 & 7,24 & $1,64 \%$ & Naik \\
\hline 4. & 2010 & 7,67 & $0,43 \%$ & Naik \\
\hline 5. & 2011 & 3,19 & $-4,48 \%$ & Turun \\
\hline 6. & 2012 & 3,06 & $-0,13 \%$ & Turun \\
\hline 7. & 2013 & 3,10 & $0,04 \%$ & Naik \\
\hline 8. & 2014 & 2,59 & $-0,51 \%$ & Turun \\
\hline 9. & 2015 & 2,70 & $0,11 \%$ & Naik \\
\hline 10. & 2016 & 2,32 & $-0,38 \%$ & Turun \\
\hline
\end{tabular}

Sumber : Laporan Keuangan PT BPR Cianjur, Jabar

Berdasarkan tabel 4.1 dapat dilihat bahwa nilai Return On Asset (ROA) PT BPR Cianjur tahun 2007-2016, berkisar antara 2,32 \% sampai dengan 7,67 \%. Angka ini berada pada posisi di atas $1,5 \%$ melebihi batas minimal sebagaimana yang diatur oleh Bank Indonesia. Angka tersebut menunjukkan bahwa secara keseluruhan PT BPR Cianjur dalam kategori sehat. Angka persentase ROA terendah terdapat pada periode 2016 yaitu sebesar $2,32 \%$, sedangkan angka persentase tertinggi terjadi pada tahun 2010 yaitu sebesar 7,67\%.

\subsection{Analisis Deskriptif NPL pada PT BPR Cianjur periode 2007-2016} berikut:

Besarnya tingkat Non Performing Loan (NPL) dapat dilihat pada tabel

Tabel 4.2

Perkembangan Tingkat Non Performing Loan (NPL)

PT BPR Cianjur periode 2007-2016 (dalam ribuan rupiah)

\begin{tabular}{|c|c|c|c|c|c|c|c|}
\hline \multirow{2}{*}{$\begin{array}{l}\text { Tahun } \\
2007 \\
\end{array}$} & \multicolumn{2}{|c|}{$\begin{array}{l}\text { Total Kredit yang } \\
\text { Diberikan }\end{array}$} & \multicolumn{2}{|c|}{$\begin{array}{l}\text { Total Kedit } \\
\text { Bermasalah }\end{array}$} & \multirow{2}{*}{$\begin{array}{c}\text { NPL (\%) } \\
5,64 \\
\end{array}$} & \multicolumn{2}{|c|}{ Perkembangan } \\
\hline & & 7.738 .021 & $\mathrm{Rp}$ & 436.219 & & & \\
\hline 2008 & & 11.031 .266 & $\mathrm{Rp}$ & 596.917 & 5,41 & $-0,23$ & Turun \\
\hline 2009 & & 13.836 .854 & $\mathrm{Rp}$ & 566.793 & 4,10 & $-1,31$ & Turun \\
\hline 2010 & $\mathrm{Rp}$ & 14.169 .833 & $\mathrm{Rp}$ & 526.458 & 3,72 & $-0,38$ & Turun \\
\hline 2011 & Rp. & 44.006 .968 & Rp. & 5.161 .392 & 11,73 & 8,01 & Naik \\
\hline 2012 & Rp. & 45.581 .501 & Rp. & 5.404 .354 & 11,86 & 0,13 & Naik \\
\hline 1192 & \multicolumn{5}{|c|}{ Muhammad Ali } & \multicolumn{2}{|c|}{ (20) Ulam } \\
\hline
\end{tabular}




\begin{tabular}{|l|ll|ll|l|l|l|}
2013 & Rp. 47.235 .507 & Rp. 4.577 .080 & 9,69 & $-2,17$ & Turun \\
\hline 2014 & Rp. 58.581 .995 & Rp. 4.327 .894 & 7,39 & $-2,3$ & Turun \\
\hline 2015 & Rp. 75.687 .445 & Rp. 5.755 .028 & 7,60 & 0,21 & Naik \\
\hline 2016 & Rp. 85.444.004 & Rp. 8.105 .601 & 9,49 & 1,89 & Naik \\
\hline
\end{tabular}

Sumber : Data perusahaan tahun 2007 sampai dengan tahun 2016 yang telah diolah kembali.

Berdasarkan tabel 4.2 di atas, dapat dilihat bahwa tingkat Non Performing Loan (NPL) PT BPR Cianjur tahun 2007-2016 berkisar antara 3,72\% sampai $11,86 \%$. Tingkat Non Performing Loan (NPL) yang diteliti adalah NPL bruto. Angka persentase tingkat Non Performing Loan (NPL) terendah terdapat pada tahun 2010 yaitu sebesar 3,72\%, Sedangkan angka persentase tertinggi terjadi pada tahun 2012 yang mencapai 11,86 ..

\subsection{Analisis Deskriptif CAR pada PT BPR Cianjur, Jabar tahun 2007 - 2016.}

Tabel 4.3

Perkembangan Capital Adequacy Ratio (CAR)

PT BPR Cianjur periode 2007-2016 (dalam ribuan rupiah)

\begin{tabular}{|c|r|r|r|r|c|}
\hline \multirow{2}{*}{ Tahun } & \multicolumn{1}{l|}{ Total Modal } & \multicolumn{1}{c|}{ ATMR } & \multicolumn{1}{|l|}{ CAR (\%) } & \multicolumn{2}{|l|}{ Perkembangan } \\
\hline 2007 & 3.154 .640 & 8.555 .709 & 36,87 & - & \\
\hline 2008 & 4.727 .219 & 12.314 .090 & 38,39 & 1.52 & Naik \\
\hline 2009 & 6.472 .486 & 15.084 .719 & 42,91 & 4.52 & Naik \\
\hline 2010 & 6.285 .470 & 15.326 .751 & 41,01 & -1.9 & Turun \\
\hline 2011 & 16.520 .373 & 52.345 .035 & 31,56 & -9.45 & Turun \\
\hline 2012 & 18.559 .152 & 55.037 .333 & 33,72 & 2.16 & Naik \\
\hline 2013 & 18.735 .133 & 55.481 .684 & 33,77 & 0.05 & Naik \\
\hline 2014 & 24.665 .451 & 67.160 .520 & 36,73 & 2.96 & Naik \\
\hline 2015 & 26.020 .157 & 84.700 .048 & 30,72 & -6.01 & Turun \\
\hline 2016 & 25.517 .539 & 96.549 .270 & 26,43 & -4.29 & Turun \\
\hline
\end{tabular}

Berdasarkan tabel 4.3 di atas, dapat dilihat bahwa tingkat CAR PT BPR Cianjur periode 2007-2016 berkisar antara 26,43\% sampai $42,91 \%$. Angka persentase tingkat CAR terendah terdapat pada tahun 2016 yaitu sebesar $26,43 \%$, Sedangkan angka persentase tertinggi terjadi pada tahun 2009 yang mencapai $42,91 \%$.

\subsection{Pertumbuhan Laba pada PT BPR Cianjur periode 2007-2016}

Tabel 4.4

Nilai Pertumbuhan Laba

PT BPR Cianjur periode 2007-2016 (dalam ribuan rupiah) 
ISSN

2460-030X
Jurnal Akuntansi Bisnis dan Ekonomi

Volume 4 No. 2, September 2018

\begin{tabular}{|c|c|c|c|c|c|}
\hline Tahun & $\begin{array}{c}\text { Laba } \\
\text { berjalan }\end{array}$ & laba thn lalu & $\begin{array}{l}\text { Pertumbuhan } \\
\text { Laba (\%) }\end{array}$ & \multicolumn{2}{|c|}{ Perkembangan } \\
\hline 2007 & 455.789 & 403.875 & 13 & & \\
\hline 2008 & 540.527 & 455.789 & 19 & 6 & Naik \\
\hline 2009 & 1.003 .898 & 540.527 & 86 & 67 & Naik \\
\hline 2010 & 1.052.342 & 1.003 .898 & 5 & 81 & Turun \\
\hline 2011 & 1.299 .576 & 1.052.342 & 23 & 18 & Naik \\
\hline 2012 & 1.791 .543 & 1.299 .576 & 38 & 15 & Naik \\
\hline 2013 & 1.891 .576 & 1.791 .543 & 6 & 32 & Turun \\
\hline 2014 & 1.824 .494 & 1.891 .576 & 4 & 2 & Turun \\
\hline 2015 & 2.094.423 & 1.824 .494 & 15 & 11 & Naik \\
\hline 2016 & 1.825 .181 & 2.094 .423 & 13 & 2 & Turun \\
\hline
\end{tabular}

Berdasarkan tabel 4.4 dapat dilihat bahwa nilai pertumbuhan laba pada PT BPR Cianjur tahun 2007-2016 berkisar antara 4\% sampai dengan $86 \%$. Pertumbuhan laba pada perusahaan tersebut tidak konsisten di mana kenaikan dan penurunan terjadi pertahun berikutnya. Angka persentase terendah terdapat pada tahun 2014 yaitu sebesar 4\%, penurunan tersebut disebabkan nilai pertumbuhan laba pada tahun lalu di tahun 2013 yaitu 1.891.576 lebih besar dibandingkan dengan tahun 2014 yang mencapai 1.824.494. Sedangkan angka persentase tertinggi terjadi pada tahun 2009 yaitu sebesar 86\% nilai pertumbuhan labanya mencapai 1.003.898.

\subsection{Pengujian Asumsi Klasik}

\section{Uji Normalitas}


Tabel 4.5

One-Sample Kolmogorov-Smirnov Test

\begin{tabular}{|ll|r|}
\hline & & \multicolumn{2}{|c|}{ Unstandardized } \\
& Residual \\
\hline N & Mean & 10 \\
& Std. Deviation &, 0000000 \\
Most Extreme Differences & Absolute &, 00158854 \\
& Positive &, 250 \\
& Negative &, 120 \\
Test Statistic & &,- 250 \\
Asymp. Sig. (2-tailed) &, 250 \\
\hline
\end{tabular}

Sumber : Output SPSS 22, data sekunder yang diolah 2017

Berdasarkan hasil uji normalitas diketahui signifikansi 0,076>0,05 maka dapat disimpulkan bahwa nilai residual berdistribusi normal.

\section{Uji Multikolineritas}

Hasil perhitungan nilai Variant Inflation Factor (VIF) menunjukan hasil tidak ada satu variabel independen yang memiliki nilai VIF lebih dari 5. Berdasarkan cofficients pada gambar diatas maka dapat diketahui bahwa nilai VIF adalah 4,520 (variabel ROA), nilai VIF 3,256 (variabel NPL), dan nilai VIF 3,497 (variabel CAR). Sehingga kesimpulannya bahwa variabel independen terbebas dari asumsi klasik multikolinearitas karena hasilnya lebih kecil dari pada 5, artinya tidak terjadi multikolinearitas untuk masing-masing variabel.

Tabel 4.5

Coefficients $^{a}$

\begin{tabular}{|l|c|c|c|c|c|}
\hline Model & $\begin{array}{c}\text { Unstandardize } \\
\text { d Coefficients }\end{array}$ & $\begin{array}{c}\text { Standardized } \\
\text { Coefficients }\end{array}$ & $\mathrm{t}$ & Sig. & Collinearity Statistics \\
\hline
\end{tabular}


ISSN

2460-030X
Jurnal Akuntansi Bisnis dan Ekonomi

Volume 4 No. 2, September 2018

\begin{tabular}{|c|c|c|c|c|c|c|c|}
\hline & B & $\begin{array}{l}\text { Std. } \\
\text { Error }\end{array}$ & Beta & & & $\begin{array}{c}\text { Toleranc } \\
\mathrm{e}\end{array}$ & VIF \\
\hline $\begin{array}{l}\text { (Constan } \\
\text { t) }\end{array}$ & ,005 & ,009 & & ,566 & ,592 & & \\
\hline $\mathrm{ROA}$ & 003, & 005, & 306 & 209, & 841, & 221, & 4,520 \\
\hline NPL & 002, & ,004 & 478, & 303, & 772, & 307, & 3,256 \\
\hline CAR & ,010 & ,017 & ,516 & $\begin{array}{r}40,17 \\
7\end{array}$ & ,000 & 286 & 3,497 \\
\hline
\end{tabular}

Sumber : Output SPSS 22, data sekunder yang diolah 2017

\section{Uji Heteroskedastisitas}

Tabel 4.6

Park Test

\begin{tabular}{|ll|r|}
\hline & & $\begin{array}{r}\text { Unstandardize } \\
\text { d Residual }\end{array}$ \\
\hline $\mathrm{N}$ & & 10 \\
Normal Parameters ${ }^{\mathrm{a}, \mathrm{b}}$ & Mean &, 0000000 \\
& Std. Deviation &, 00158854 \\
Most Extreme Differences & Absolute &, 250 \\
& Positive &, 120 \\
& Negative &,- 250 \\
Test Statistic & &, 250 \\
Asymp. Sig. (2-tailed) & &, $076^{\mathrm{C}}$ \\
\hline
\end{tabular}

Sumber : Output SPSS 22, data sekunder yang diolah 2017

Berdasarkan hasil uji heterokedastisitas dengan menggunakan metode statistika park test dari ini akan terlsihat pada tabel 4.20 diperoleh nilai signifikan dari variabel independen sebesar 0,076

Kesimpulan: signifikan > 0,05 maka bebas dari unsur heterokedastisitas.

\section{Uji Autokorelasi}

Tabel 4.7

Model Summary

\begin{tabular}{|l|r|r|r|r|c|}
\hline Model & $\mathrm{R}$ & $\mathrm{R}$ Square & $\begin{array}{c}\text { Adjusted R } \\
\text { Square }\end{array}$ & $\begin{array}{c}\text { Std. Error of } \\
\text { the Estimate }\end{array}$ & $\begin{array}{c}\text { Durbin- } \\
\text { Watson }\end{array}$ \\
\hline 1 &, 146 &, 236 &, 486 &, 00195 & 2,522 \\
\hline
\end{tabular}

Sumber : Output SPSS 22, data sekunder yang diolah 2017

Dikatakan bebas autokorelasi apabila nilai Durbin Watson berada diantara DU dan 4 - DU, atau DU $<$ DW $<4$-DU

$2,0163<2,522<(4-2,0163)$

Jadi dapat disimpulkan bahwa bebas autokorelasi. 


\subsection{Pengaruh ROA terhadap Pertumbuhan Laba pada PT. BPR Cianjur periode 2007-2016}

Analisis regresi linear berganda pada variabel ROA (Return On Asset) terhadap pertumbuhan laba pada PT BPR Cianjur periode 2007-2016 untuk mengetahui adakah pengaruhnya diperoleh berdasarkan output software SPSS versi 22 , dan dihitung dengan cara uji hipotesis dengan uji t.

Tingkat signifikasi variabel berikut ini adalah hasil analisis pengaruh ROA terhadap pertumbuhan laba secara parsial pada tabel 4.8 sebagai berikut:

Tabel 4.8

Pengaruh variabel ROA, NPL, dan CAR terhadap variabel Pertumbuhan Laba Coefficients $^{a}$

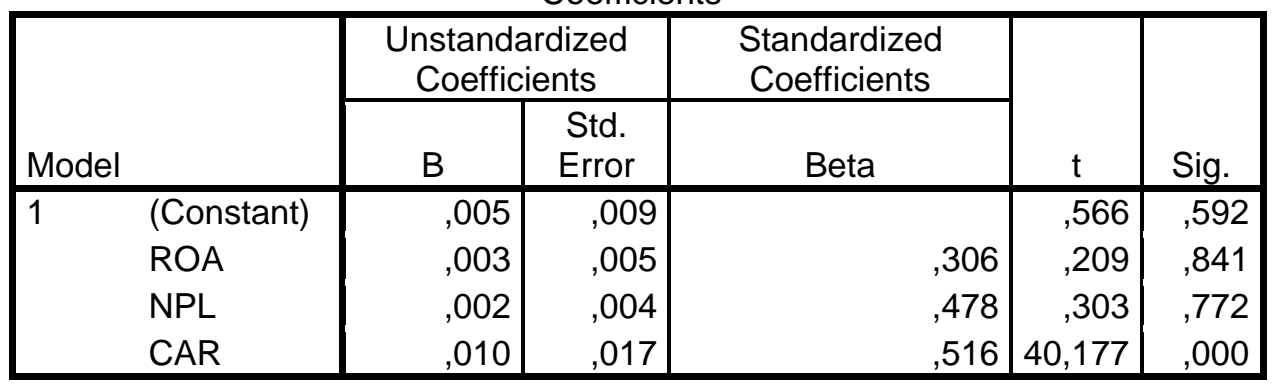

Sumber : Output SPSS 22, data sekunder yang diolah 2017

Selanjutnya adalah pengujian hipotesis dengan menggunakan uji $t_{\text {hitung }}$ yang dibandingkan dengan $t_{\text {tabel. }}$. Dimana untuk tingkat alpha 0,05 , dan untuk $\mathrm{T}$ tabel $=\mathrm{t}(\mathrm{a} / 2: \mathrm{n}-\mathrm{k})=\mathrm{t}(0,025: 7)=2,365$.

Kemudian pada tabel 4.15 diketahui bahwa t-hitung pada ROA sebesar 0,209 . Nilai tersebut menunjukkan bahwa nilai t-hitung lebih kecil dibandingkan dengan t-tabel.

Variabel ROA dari hasil penelitian ini t hitung $<\mathrm{t}$ tabel, maka $\mathrm{H}_{0}$ ada pada daerah penerimaan, berarti $\mathrm{H}_{\mathrm{a}}$ ditolak atau tidak ada pengaruh pengaruh yang signifikan terhadap Pertumbuhan Laba pada PT BPR Cianjur. Sehingga hasil penelitian secara parsial ini bertolak belakang dengan hasil penelitian Muhammad Isnaini Fathoni, dkk (2012: 22).

Berdasarkan ketentuan tersebut variabel ROA tidak ada pengaruh yang signifikan terhadap Pertumbuhan Laba pada PT BPR Cianjur. Hal ini disebabkan disebabkan karena jumlah fenomena yang ditemukan cukup banyak, yaitu sebanyak dalam 5 periode antara periode 2007-2016.

\subsection{Pengaruh NPL terhadap Pertumbuhan Laba pada PT. BPR Cianjur periode 2007-2016.}

Hasil analisis regresi linear berganda pada variabel NPL (Non Performing Loan) terhadap pertumbuhan laba pada PT BPR Cianjur tahun 2007-2016 
untuk mengetahui adakah pengaruhnya diperoleh berdasarkan output software SPSS versi 22, dan dihitung dengan cara uji hipotesis dengan uji t.

Selanjutnya adalah pengujian hipotesis dengan menggunakan uji $t_{\text {hitung }}$ yang dibandingkan dengan $t_{\text {tabel. }}$. Dimana untuk tingkat alpha 0,05 , dan untuk $t$ tabel $=\mathrm{t}(\mathrm{a} / 2: \mathrm{n}-\mathrm{k})=\mathrm{t}(0,025: 7)=2,365$.

Pada tabel 4.15 diketahui bahwa t-hitung pada NPL sebesar 0,303 . Nilai tersebut menunjukkan bahwa nilai t-hitung lebih kecil dibandingkan dengan ttabel.

Berdasarkan ketentuan tersebut variabel NPL dari hasil penelitian ini $t$ hitung $<\mathrm{t}$ tabel, maka $\mathrm{H}_{0}$ ada pada daerah penerimaan, berarti $\mathrm{H}_{\mathrm{a}}$ ditolak atau tidak ada pengaruh yang signifikan terhadap Pertumbuhan Laba pada PT BPR Cianjur. Sehingga hasil penelitian secara parsial ini bertolak belakang dengan hasil penelitian Muhammad Isnaini Fathoni, dkk (2012: 22).

Kemudian pada pernyataan diatas variabel NPL yaitu tidak ada pengaruh yang signifikan terhadap Pertumbuhan Laba pada PT BPR Cianjur. Hal ini disebabkan karena jumlah fenomena yang ditemukan cukup banyak, yaitu sebanyak dalam 6 periode antara periode 2007-2016 .

\subsection{Pengaruh CAR (Capital Adequacy Ratio) terhadap Pertumbuhan Laba pada PT. BPR Cianjur periode 2007-2016.}

Hasil analisis regresi linear berganda pada variabel CAR (Capital Adequacy Ratio) terhadap pertumbuhan laba pada PT BPR Cianjur tahun 2007-2016 untuk mengetahui adakah pengaruhnya diperoleh berdasarkan output software SPSS versi 22, dan dihitung dengan cara uji hipotesis dengan uji t.

Selanjutnya adalah pengujian hipotesis dengan menggunakan uji $t_{\text {hitung }}$ yang dibandingkan dengan $t_{\text {tabel. }}$. Dimana untuk tingkat alpha 0,05 , dan untuk $\mathrm{T}$ tabel $=\mathrm{t}$ $(\mathrm{a} / 2: \mathrm{n}-\mathrm{k})=\mathrm{t}(0,025: 7)=2,365$.

Kemudian pada tabel 5.1 diketahui bahwa t-hitung pada CAR sebesar 40,177 . Nilai tersebut menunjukkan bahwa nilai t-hitung lebih besar dibandingkan dengan t-tabel.

Berdasarkan ketentuan tersebut variabel CAR dari hasil penelitian ini $t$ hitung $>\mathrm{t}$ tabel, maka $\mathrm{H}_{0}$ ada pada daerah penolakan, berarti $\mathrm{H}_{\mathrm{a}}$ di terima atau ada pengaruh yang signifikan positif CAR terhadap Pertumbuhan Laba pada PT BPR Cianjur. Sehingga hasil penelitian secara parsial ini mendukung hasil penelitian Muhammad Isnaini Fathoni, dkk (2012: 22)

\subsection{Pengaruh ROA (Return On Assets), NPL (Non Performing Loan), dan CAR (Capital Adequacy Ratio) secara simultan terhadap Pertumbuhan Laba pada PT. BPR Cianjur Jabar Tahun 2007-2016}

Setelah diketahui pengaruh masing-masing variabel independen terhadap variabel dependen, yaitu pengaruh Return On Assets (ROA), NPL (Non Performing Loan), dan CAR (Capital Adequacy Ratio) terhadap Pertumbuhan Laba pada PT. BPR Cianjur periode 2007-2016. Selanjutnya penulis menganalisis mengenai pengaruh variabel Return On Assets (ROA), NPL (Non Performing Loan), dan CAR (Capital Adequacy Ratio) terhadap Pertumbuhan Laba pada PT. BPR Cianjur periode 2007-2016 secara simultan (bersama- 
sama), dimana penulis menggunakan output dari tabel ANOVA untuk menghasilkan uji $F$ dan koefisien determinasi atau Adjusted $R$ Square menggunakan output SPSS 22 dari tabel Model Summary.

Hasil uji F dapat dilihat dalam tabel dibawah ini :

Tabel 4.9

ANOVA

\begin{tabular}{|rr|r|r|r|r|l|}
\hline \multicolumn{2}{|l|}{ Model } & \multicolumn{1}{|c|}{$\begin{array}{c}\text { Sum of } \\
\text { Squares }\end{array}$} & df & Mean Square & F & Sig. \\
\hline 1 & Regression &, 021 & 3 &, 007 & 1879,238 &, $000^{\mathrm{b}}$ \\
& Residual &, 000 & 6 &, 000 & & \\
& Total &, 021 & 9 & & & \\
\hline
\end{tabular}

Sumber : Output SPSS 22, data sekunder yang diolah 2017

Berdasarkan output diatas diketahui bahwa nilai $F_{\text {hitung }}$ adalah sebesar 1879,238, dan $F$ tabel sebesar 4,76 . Nilai signifikasi untuk pengaruh $X 1, X 2$, dan $X 3$ secara simultan terhadap $Y$ adalah sebesar $0,000<0,05$ dengan nilai $F$ hitung 1879,238> $\mathrm{F}$ tabel 4,76, sehingga dapat disimpulkan bahwa $\mathrm{H}_{0}$ ada pada daerah penolakan, berarti $\mathrm{H}_{\mathrm{a}}$ di terima atau ada pengaruh variabel $R O A, N P L$ dan CAR secara simultan terhadap variabel Pertumbuhan Laba pada PT BPR Cianjur PT BPR Cianjur, Tbk, Tahun 2007-2016.

Hasil uji Determinasi (Adjusted $R$ Square) dapat dilihat dalam tabel dibawah ini :

Tabel 4.10

Model Summary

\begin{tabular}{|l|r|r|r|c|}
\hline Model & $\mathrm{R}$ & $\mathrm{R}$ Square & Adjusted R Square & $\begin{array}{c}\text { Std. Error of the } \\
\text { Estimate }\end{array}$ \\
\hline 1 &, 146 &, 236 &, 486 &, 00195 \\
\hline
\end{tabular}

Sumber : Output SPSS 22, data sekunder yang diolah 2017

Berdasarkan output diatas diketahui nilai Adjusted $\mathrm{R}$ Square sebesar 0,486 , hal ini mengandung arti bahwa pengaruh variabel $\mathrm{X} 1, \mathrm{X} 2$, dan $\mathrm{X} 3$ secara simultan terhadap variabel $Y$ adalah sebesar $48,6 \%$. Yakni, 48,6\% variasi pertumbuhan laba dapat dijelaskan oleh variasi dari ketiga variabel independen yang terdiri dari ROA, CAR, dan NPL, sedangkan sisa nya sebesar $51,4 \%(100 \%-48,6 \%)$ dipengaruhi oleh faktor-faktor lain yang tidak dimasukkan dalam model.

Persamaan Regresi Linear yang terbentuk adalah :

$\mathrm{Y}=0,005+0,003 \mathrm{X} 1+0,002 \mathrm{X} 2+0,010 \mathrm{X3}$

Berikut penjelasan untuk hasil persamaan regresi tersebut:

1. Konstanta menunjukkan angka 0,005 yang berarti jika semua variabel bebas memiliki nilai 0 maka variabel terkaitnya pertumbuhan laba sebesar 0,005 atau menambah sebesar $0,5 \%$. 
ISSN

2460-030X

2. Koefisien ROA (X1) sebesar 0,003 hal ini menunjukkan bahwa setiap penambahan ROA $1 \%$ akan meningkatkan pertumbuhan laba sebesar $0,3 \%$.

3. Koefisien NPL (X2) sebesar 0,002 hal ini menunjukkan bahwa setiap penambahan NPL 1\% akan menurunkan pertumbuhan laba sebesar $0,2 \%$.

4. Koefisien CAR (X3) sebesar 0,010 hal ini menunjukkan bahwa setiap penambahan CAR $1 \%$ akan meningkatkan pertumbuhan laba sebesar $1 \%$.

\section{KESIMPULAN}

1. Secara parsial, pengaruh ROA memiliki pengaruh yang tidak signifikan terhadap pertumbuhan laba. Hal ini sesuai dengan hasil pengujian statistik yang menunjukkan $\mathrm{H}_{0}$ ada pada daerah penerimaan, berarti $\mathrm{H}_{\mathrm{a}}$ ditolak dimana thitung lebih kecil dari pada t tabel $(0,209<2,365)$.

2. Secara parsial, pengaruh NPL memiliki pengaruh yang tidak signifikan terhadap pertumbuhan laba. Hal ini sesuai dengan hasil pengujian statistik yang menunjukkan $\mathrm{H}_{0}$ ada pada daerah penerimaan, berarti $\mathrm{H}_{\mathrm{a}}$ ditolak dimana thitung lebih kecil dari pada t tabel $(0,303<2,365)$.

3. Secara parsial, pengaruh CAR memiliki pengaruh yang signifikan terhadap pertumbuhan laba. Hal ini sesuai dengan hasil pengujian statistik yang menunjukkan $\mathrm{H}_{0}$ ada pada daerah penolakan, berarti $\mathrm{H}_{\mathrm{a}}$ diterima dimana $\mathrm{t}$ hitung lebih besar dari pada t tabel $(40,177>2,365)$.

4. Secara Simultan pengaruh ROA, NPL dan CAR memiliki pengaruh yang signifikan terhadap pertumbuhan laba pada PT BPR Cianjur Tahun 20072016 sebesar $48,6 \%$.

\section{DAFTAR PUSTAKA}

Brigham, Eugene F dan Joel F. Houston. Dasar-Dasar Manajemen Keuangan. Jakarta: Salemba Empat. 2010.

Frianto Pandia. Manajemen Dana dan Kesehatan Bank. Jakarta: PT RINEKA CIPTA.2012.

Gatot Supramono. Perbankan dan Masalah Kredit. Jakarta: PT Rineka Cipta. 2009.

Muhammad Isnaini Fathoni, dkk. Pengaruh Tingkat Kesehatan Bank Terhadap Pertumbuhan Laba Pada Perusahaan Sektor Perbankan. Jurnal Universitas Muhammadiyah Surakarta. Vol. 13, No. 1, Juni 2012 : 15-29.

Siswanto Sutojo. Menangani Kredit Bermasalah. Jakarta: Pustaka Binaman Pressindo.2007.

Sofyan Syafri Harahap. Teori Akuntansi Edisi Revisi 2011. Jakarta: PT RAJA GRAFINDO PERSADA.2011.

Sugiyono. 2011. Metode Penelitian Kuantitatif Kualitatif dan $R$ \& D. Bandung: Alfabeta.

Tim Penyusun Pedoman Akuntansi Perbankan Indonesia. Pedoman Akuntansi Perbankan Indonesia (Revisi 2008). Jakarta: 2008

Tim Penyusun Pedoman Akuntansi Perbankan Indonesia. Pedoman Akuntansi Perbankan Indonesia Buku 2. Jakarta: 2008 